\title{
Senpai: Learner Responses to a Near-Peer Role Modeling Intervention
}

\section{Jason R. Walters \\ Nagoya University of Foreign Studies}

\section{Reference Data:}

Walters, J. R. (2020). Senpai: Learner responses to near-peer role modeling intervention. In P. Clements, A. Krause, \& R. Gentry (Eds.), Teacher efficacy, learner agency. Tokyo: JALT. https://doi.org/10.37546/JALTPCP2019-14

Though Japanese learners often express a preference for so-called "native" English teachers, a growing body of research indicates that their development of multilingual identity is more positively influenced by those with whom they readily identify-other successful Japanese learners. This mixed methods study, conducted in tandem with an existing communication strategy curriculum, explored university students' responses to a "near-peer role modeling" intervention combining prerecorded video with reflective practice. Participants included two groups, both majoring in Japanese, enrolled in a compulsory 1st-year English conversation tutorial course. Results indicate that less confident students may experience positive belief changes and increased classroom participation following exposure to near-peer role models. More confident learners did not exhibit these changes to a significant degree. Moreover, following this intervention, lower-performing students responded more positively to statements expressing self-efficacy. Participants' use of Japanese respect language may illuminate to what extent near-peers are valued as role models.

日本の学習者達は「英語母語話者」である英語教師から指導を受ける事が理想的だという意見をよく示すが、近年の研究 調査では、学習者にとつて最もお手本となる人物は自身の身近に存在する英語を使いこなす日本人英語学習者(NPRM)である と主張されている。本研究では、混合研究法を用い1学期間のNPRM活動を通して学習者の信念の变化を探究した。映像と反 省的実践を用いた実験的手法は、既存の会話手法習得の為のカリキュラムと並行して導入された。結果として、英語能力に自 信のない学習者達は模範的な日本人から受ける自己効力感について肯定的な変化を示し、学習活動への参加が増加した。一 方で、英語能力に自信のある学習者達は明確な变化を示さなかった。量的な結果は面談調査と映像を見た後の学習者による 感想文を用いた質的データにより解釈が可能となつた。参加者たちが使用する日本語の尊敬語である先輩という表現はどの 級友がロールモデルであると理解されているかの程度を示している。本研究は独特な教育環境によって行われた為、更なる 詳細な研究調査が必要となるだろう
7 nglish education in Japan involves foreign teachers whose presence may reinforce unrealistic expectations of fluency (Cook, 1999), while access to confident and proficient Japanese speakers of English, perhaps more effective exemplars for young Japanese learners, seems comparatively lacking. According to Murphey and Arao (2001), near-peers are "people who might be near' to us in several ways: age, ethnicity, gender, interests, past or present experiences, and also in proximity and frequency of social contact" (p. 1), and access to these individuals may influence learners' attitudes and choices. Using an experimental intervention exposing students to successful near-peers, this study investigates changes in self-efficacy beliefs among two groups of 1st-year Japanese university students. This paper summarizes the ongoing study, illustrating the potential value of near-peer role modeling in small group tutorial classes and describes different responses by learners of varying proficiency and reported confidence.

\section{Native Speakerism in EFL}

A cursory review of English conversation textbooks in Japan's public schools reveals a number of common themes and content topics: travel, food, holidays, and the like. These topics, as well as their attending vocabulary lists, communication strategies (CSs), and syntactic structures, are commonly accompanied by a cast of illustrated characters and presented via a loose narrative depicting young Japanese people "exchanging culture" with young non-Japanese people, perhaps in study-abroad programs or in foreign exchange programs (Cottle, 2009; Matsuda, 2001). Frequently, exchanging culture is shown to be accomplished by identifying and enumerating customs or items of material culture and allocating them into proprietary and irreconcilable "Japanese" and "not Japanese" categories. A lesson's characters may explain unique traditions in terms of collective ownership, where in Japan we eat rice, but people in other countries eat bread (Ito, 2016; Stapleton, 2000). Law (1995) reflects on the implications of taking this view in education, writing that "the diversity of other languages and cultures is simply collapsed into the uniformity of what is not- 
us, outside, strange-muko or "over there." The world becomes a binary choice of us and them (Law, 1995, p. 216, cited in McVeigh, 2002, p. 149). The likely unintentional implication of this version of cross-cultural communication; beyond bread/rice, shoes indoors/no shoes indoors, or Halloween/Setsubun, there lies Japanese/Englishone belonging to $u s$, the other to them. In classrooms where during English lessons (exclusively), Japanese sensei is routinely displaced by a foreign assistant perceived to be a more suitable teacher (Lipovsky \& Mahboob, 2010; Phillipson, 1992; Wang \& Lin, 2013), and where students are heard to confess variations of, "I can't speak English because I am Japanese," or "Japanese people can't speak English well," the question arises as to what degree English deficiency is perceived to be a distinguishing feature of Japanese identity. McVeigh proposes that "for some students, learning English well contaminates, or at least threatens, their ethnocultural and national identity" (2002, p. 155), while Reischauer and Jansen (1988) conclude that "knowing a foreign language too well, it is feared, would erode the uniqueness of the Japanese people" (p. 392, cited in Turnbull, 2017, p. 213). A 2017 survey of Japanese university students revealed that 71 percent agreed that "speaking Japanese" is an essential indicator of Japanese identity, with one-third of respondents reporting the belief that English study reduces one's "Japaneseness" (Turnbull, 2017, pp. 218-219).

These factors, in light of the perceived value of so-called "native" English speaking teachers (NESTs), may impair learners' capacity to view their Japanese peers and teachers as suitable language learning partners or exemplars. Cook (1999) argues that pressure on learners to acquire "native-like" language by exposing them to NESTs may deemphasize their development of interlanguage through peer communication and reinforces their perception of learners as "failed native speakers" rather than multicompetent speakers in the process of development (p. 204). To counteract this, Cook suggests that placing classroom emphasis on successful second-language (L2) users provides a framework wherein learners can recognize their own potential through a sense of shared identity, cultivating beliefs that they are truly using $\mathrm{L} 2$ to communicate rather than attempting imitations of native speakers. Bandura's finding that "seeing or visualizing people similar to oneself perform successfully typically raises efficacy beliefs in observers that they themselves possess the capabilities to master comparable activities" (1997, cited in Dörnyei \& Murphey, 2003, p. 128) speaks to the idea that learners in need of greater self-confidence may benefit from exposure to successful learners with whom they readily identify and favors Cook's recommendation that learners be provided opportunities to observe their peers communicating successfully in L2.

\section{Near-Peer Role Models and Learner Beliefs}

Murphey (1998) argues that students' need for role models in language learning cannot be adequately fulfilled by NESTs, remarking that "foreigners in Japan are culturally distant role models for students" (p. 203). Rather, Japanese teachers of English or slightly more advanced learners attending the same institution, who share learners' cultural background and are close in age, are potentially more valuable as near-peer role models (NPRMs).

Perhaps the most familiar body of research on the topic of NPRMing was conducted in a series of experiments at Nanzan University (Kichiji, 1997; Kushida, 1995 Murphey \& Murakami, 1998; Yamashita, 1998), in which learners were shown videos of older or more advanced students making encouraging comments about English learning. These comments included endorsements of the belief that Japanese people can learn to speak English, promoted goal-setting, and advocated taking risks and making mistakes. Data collected before and after this intervention indicated positive changes in these students' beliefs about their English learning potential. In a follow-up study, Murphey and Arao (2001) found that the most significant positive changes in self-efficacy beliefs were reported by learners who did not feel that they had achieved sufficient success in their previous experiences learning English. The importance of near-peers in language learning is supported by a number of subsequent studies: Haye-Matsui documented the impact of female exemplars on the language learning choices made by young women (2016), and Zirkel discusses the significance of race and gender-matched role models in the development of academic identity in students of color (2002).

\section{Research Questions}

With reference to Murphey (1998), the following questions guide this ongoing research effort:

RQ1. To what extent does exposure to near-peer role models affect learners' reported self-efficacy beliefs?

RQ2. How is NPRMing received by learners of varying proficiency and reported confidence?

\section{Method}

To ensure meaningful exploration of this study's research questions while safeguarding potential findings from avoidable biases or oversights, a variety of data collection 
instruments were employed in an explanatory, sequential mixed methods design. Within each phase, instruments were designed to clarify and add richness to previously collected data, requiring that data from each phase inform the development of subsequent phases. Quantitative results were contextualized using qualitative data sources including interviews and reflections.

\section{Participants}

Following the decision that participant groups consist of first-year non-English major students enrolled in compulsory discussion tutorials at a private Japanese university, Japanese major students were ultimately selected in order to minimize the impact of externalities and to lessen procedural complications with data collection as they generally:

1. did not enroll in elective English courses

2. pursued degrees unrelated to English teaching

3. were believed to display more consistent class attendance than learners in other departments, and

4. attended the researcher's class on the same days, allowing for close supervision of assistants' data collection.

Participants were separated by class period, with Group A $(n=58)$ participating in the experimental NPRM activities, and Group B $(n=56)$ receiving the standard tutorial class.

\section{Ethical Considerations}

Participants received a form requesting consent for data collection written in both English and Japanese (see Appendix A). The form requested permission for instructors to record class activities and interviews, retain copies of student work, and to share information with other teachers and researchers. Although several students wished not to be video recorded, all participants provided consent to data collection. Though many participants consented to the use of their real names, pseudonyms are used in the following sections. All phases of the project were carried out as a sanctioned pilot program in coordination with department faculty with adherence to institutional guidelines.

\section{Data Collection}

This research examined changes in learner beliefs over time following an intervention incorporating NPRM video recordings and reflective practice. A sequential approach to data collection was required and was carried out in three primary phases:

1. questionnaires examining attitudes about language learning at the start of the semester and follow-up interviews with focus students;

2. ongoing collection of classroom data, student reflections, student grades, and teacher observations in the form of field notes; and

3. final questionnaires and follow-up interviews examining end-of-semester attitudes and beliefs.

The Beliefs about Language Learning Inventory (BALLI) survey developed by Horwitz (1987), was modified for this study. The modified BALLI (MBALLI) added items intended to examine learners' English learning histories. A second set of additional items was created for the purpose of exploring issues of Japanese identity, and the phrasing of existing items was modified to assume Japanese as the respondents' native language. Open-ended items were included to assist in developing interview topics. The MBALLI was translated into Japanese, proofread, and piloted in collaboration with Japanese research assistants (see Appendix B). Participants were given the option to complete the questionnaire anonymously; of the 114 participants, 67 elected to remain anonymous.

\section{Focus Students}

Focus students were invited to participate in voluntary interviews, the first of which was held during the 3rd week of the semester; follow-up interviews were scheduled for the final week. The following criteria were considered in selecting interviewees in order to maximize the diversity of respondents' experience and proficiency:

1. respondents' perceived support from Japanese role models in language learning;

2. respondents' confidence and perceived English proficiency as self-reported in survey responses (see Table 1); and

3. researchers' observations of in-class interaction during two class periods using a rubric developed by Bowyer (2018) to evaluate the content of learner talk, level of participation, and efforts to improve comprehensibility (see Table 1).

Six students were selected from the pool of consenting participants. The focus group was not gender balanced, with a ratio of five female students to one male student.

However, this ratio is consistent with the demographics of the university, wherein female students outnumber their male classmates at a ratio of approximately six to one. Student responses to interview questions were translated from Japanese by the author; prior to coding, translations were reviewed and verified by bilingual Japanese research assistants. 
Table 1. Focus Students: Selected Characteristics

\begin{tabular}{lcc}
\hline Learner & Perceived ability (of 5) & Proficiency (of 9, see Appendix C) \\
\hline Yukari & 4.17 & 9 \\
Megumi & 2 & 8 \\
$\mathrm{Ai}$ & 1.83 & 5 \\
Mayuko & 4 & 7 \\
Takayuki & 1.83 & 3 \\
Juri & 1.17 & 7 \\
\hline
\end{tabular}

Note: Participants' perceived ability was established by their agreement with the questionnaire items "I have English language learning aptitude," "I believe I will learn to speak English well," and

"I am able to help others improve their English ability" according to a 5-point Likert scale.

\section{Intervention}

This study was informed by Murphey's findings in its use of prerecorded video to expose learners to NPRMs. In Murphey's research, NPRMs address viewers directly, making unambiguous and positive statements about language learning. The intervention employed in the present study took a more indirect approach, exposing students to examples of authentic English communication between slightly older and more advanced students from the same university. Two 2nd-year students were recruited to perform in a series of these videos and were compensated for their time according to institutional remuneration policies. In each 5-minute video, the pair engages in extemporaneous discussion about a commonplace content topic (e.g., food, travel, and the like) while demonstrating the course's target CSs to repair communication difficulties. To promote authenticity, the NPRMs were given no advance notice regarding topics and received no prompting.

The NPRM videos were viewed biweekly by all members of the intervention group (Group A). After viewing these videos as homework, participants completed a reflection assignment which included awareness-raising items that required participants to identify the NPRMs' use of CSs, to notice and report on aspects of the conversation, and to relate their impressions of the videos to their own development. Topics for classroom pair discussion were coordinated to match each video. Although members of Group B also discussed these topics, they did not carry out the video activities or reflective practice. Survey responses, interviews, reflections, and classroom assessment scores were collected from both groups' participants by the researcher and assistants for analysis.

\section{Results and Analysis}

These data, collected at different points in time, afford an understanding of the manner in which self-efficacy beliefs may change over time and in response to repeated engagement in NPRM activities. Responses to survey and interview items gathered early in the semester established reference points by which later responses were evaluated; focus students' responses provided greater depth and context to generalizations posited based on questionnaire and observational data. As learner beliefs are complex, malleable, and display high individual variation, no attempt can be made to extend these generalizations beyond the local context.

\section{Preliminary Analysis of Survey Data}

To begin probing differences in change between the two groups, it was first necessary to determine the appearance of any significant pre-existing differences in reported learner beliefs that might confound the results. These ordinal data displayed non-parametric distribution and represented two independent groups, meeting the conditions for a Mann-Whitney U test (McKnight \& Najab, 2010). This test found differences between Group A and B to be insignificant at the 0.05 level for relevant items.

After establishing that learner beliefs in April were largely consistent between Group A (the intervention group) and Group B, Group B's April and July survey results were tested in order to identify any significant changes in beliefs reported by learners who had not received the NPRM intervention. The results of this analysis were as expected; apart from two items, all differences between Group B’s April and July survey results were found to be statistically insignificant at the 0.05 level. The two survey items showing significant change were related to cultural immersion in language learning. As Group B participants' elective coursework included an extensive study-abroad component, it was anticipated that this group would exhibit belief changes regarding these items.

After confirming generally insignificant changes in reported beliefs among members of the group that did not receive the intervention, a final test was necessary to compare July survey results from both groups to determine whether any items returned significant differences between groups at the end of the study. It is feasible that any significant differences found here at the 0.05 level would indicate that the intervention was successful in those domains. Significant differences returned in April that did not appear in July would indicate the same. These data sets belonging to two independent groups required a second Mann-Whitney $\mathrm{U}$ test to be conducted to examine changes in reported learning beliefs exhibited by members of either group between April and July. This test 
identified significant changes in responses among the intervention group members at the 0.05 level for the items shown below in Table 2 .

Table 2. Significant Changes Between Groups A (Intervention) and B (Comparison)

\begin{tabular}{|c|c|c|c|c|c|c|c|}
\hline \multirow[b]{2}{*}{ Item } & \multicolumn{3}{|c|}{ Group A $(n=48)$} & \multicolumn{3}{|c|}{ Group B $(n=53)$} & \multirow[b]{2}{*}{$p$ value } \\
\hline & $\mathrm{M}$ & SD & Range & M & SD & Range & \\
\hline $\begin{array}{l}\text { Q1. Learning a foreign } \\
\text { language is easier for } \\
\text { children than for adults. }\end{array}$ & 3.96 & 0.68 & 1-4 & 4.2 & 0.7 & 3-5 & .041 \\
\hline $\begin{array}{l}\text { Q6. Japanese people } \\
\text { are good at learning } \\
\text { languages. }\end{array}$ & 2.79 & 0.68 & $1-5$ & 2.49 & 0.78 & $1-4$ & .034 \\
\hline $\begin{array}{l}\text { Q10. It is better to learn } \\
\text { English in English- } \\
\text { speaking countries }\end{array}$ & 3.96 & 0.85 & $2-5$ & 4.47 & 0.58 & 3-5 & .002 \\
\hline $\begin{array}{l}\text { Q23. Women are better } \\
\text { than men at learning } \\
\text { English. }\end{array}$ & 2.33 & 0.78 & $1-3$ & 2.75 & 0.85 & $1-5$ & .014 \\
\hline $\begin{array}{l}\text { Q32. I can help other } \\
\text { Japanese students to } \\
\text { improve their English. }\end{array}$ & 3.06 & 0.66 & $1-5$ & 3.04 & 0.53 & $1-5$ & .024 \\
\hline
\end{tabular}

That Q10 appears here is unsurprising-as previously stated, as the intervention group's coursework included an emphasis on study-abroad preparation, this change was anticipated. The items concerning the perceived language learning success of younger learners and women were unexpected, though exploration of this result falls outside the scope of this study. Based on the results of these tests, the remaining two statements associated with learner beliefs highlighted key areas for qualitative analysis and were discussed in follow-up interviews.

\section{Examination of Learner Responses}

Although survey responses indicate that several of the Group A's beliefs underwent some degree of change following the introduction of NPRM activities, the applied tests have significant limitations in light of the fact that nearly half of the respondents elected to remain anonymous; this obscures the nature of belief changes among individual respondents or groups within the sample. However, an analysis of field notes, learner reflections, and interviews conducted with focus students, supported by survey data from participants who chose to self-identify, indicate that learners reporting lower confidence responded differently to NPRM activities than did their more confident peers. Additionally, an examination of questionnaire responses in high and low performing students in both groups indicated a positive change in self-efficacy beliefs among lowerperforming students who received the intervention.

The following subsections explore interviews, reflections, and classroom performance in order to examine changes in learners' self-efficacy beliefs as well as their impressions of the NPRMs.

Lower Confidence May Lead to More Positive Perception of NPRMs Based on their early findings, Murphey and Arao (2001) suggested that learners reporting dissatisfaction with their L2 development may benefit more from NPRMs than more confident learners. An examination of several data sources from this project appears to validate this inference.

Initial survey results revealed that focus students Takayuki, Juri, and Ai possessed low confidence in their English ability when compared to Mayuko and Yukari (see Table 1). This was later corroborated by their interview responses and instructors' field notes . A review of these students' reflections (indicated by italics) and interview comments indicate that the low-confidence group found the NPRM activities more helpful and enjoyable.

Takayuki: Because they are senpai, it makes me think, "Oh, I can speak like them someday." "It allows us to have a goal, by watching other Japanese people, that I can be like them."

Ai: $\quad$ Video watching homework [was most helpful]. Watching the senpai talk, who are close to my age, it's easy to grasp by listening to someone similar to me.

"I thought I also talk to my friend in English when I see this conversation." 
Juri:

The YouTube video watching, it's good for me ... it's a good way for me to study.

"I would also like use reactions like [Speaker A] ... I want to become like them."

Although the less confident students readily identified NPRM activities as valuable, Yukari and Mayuko believed that other classroom activities were more effective; furthermore, they were more likely to criticize the NPRMs for errors. The NPRM video activities were described to the students as an opportunity to watch and listen to CS usage in authentic conversation; beyond this, the concept of NPRMing was not explained. Yukari and Mayuko appear to have assumed that the NPRM videos featured Japanese learners rather than so-called native speakers in order to illustrate difficulties experienced by Japanese speakers of English.

Yukari: "If we watch Japanese people, we can notice their mistakes."

"They made many mistakes and that is difficult for me to hear."

Mayuko: The English is middle level ... not high level.

"By watching Japanese peoples' conversation, we can see difficult points in conversation."

"I didn't [enjoy the conversation] because I want [Speaker A] to try to continue conversation more."

It is noteworthy that the learners reporting higher confidence interpreted the video activities as somewhat unpleasant tasks meant to highlight communication difficulties but the less confident learners described the videos as inspiring feelings of motivation and enjoyment. The focus students' word choice provides cultural insight into the participants' perception of the intended NPRMs: The more advanced and confident students more often referred to the NPRMs as "Japanese people," "the speakers," or identified them by name, and those who reported that the videos were helpful were more likely to use Japanese respect language, recognizing the NPRMs as "senpai" (Japanese, "social or professional superior, senior") or "older students."

\section{NPRMing May Positively Impact Self-Efficacy Beliefs in Lower} Performing Students

Survey data was revisited after discovering that learners with lower reported confidence may be more likely to respond positively to NPRM activities. This finding raised the question of whether a positive response to the intervention may lead to improved classroom performance. The large number of anonymous respondents in both groups precluded a full comparison of performance scores (based on teacher assessment, attendance, and homework completion). Fortunately, the top and bottom five performers in both Groups A and B had choses to self-identify, allowing changes in these individuals' questionnaire responses to be examined directly.

Figure 1 provides a visual review of differences in learner self-efficacy beliefs reported by the most successful and least successful students in both Group A and B. Highperforming students' agreement with statements such as "I have language learning aptitude" remained relatively consistent, as did the reported beliefs of low performers in the Group B.

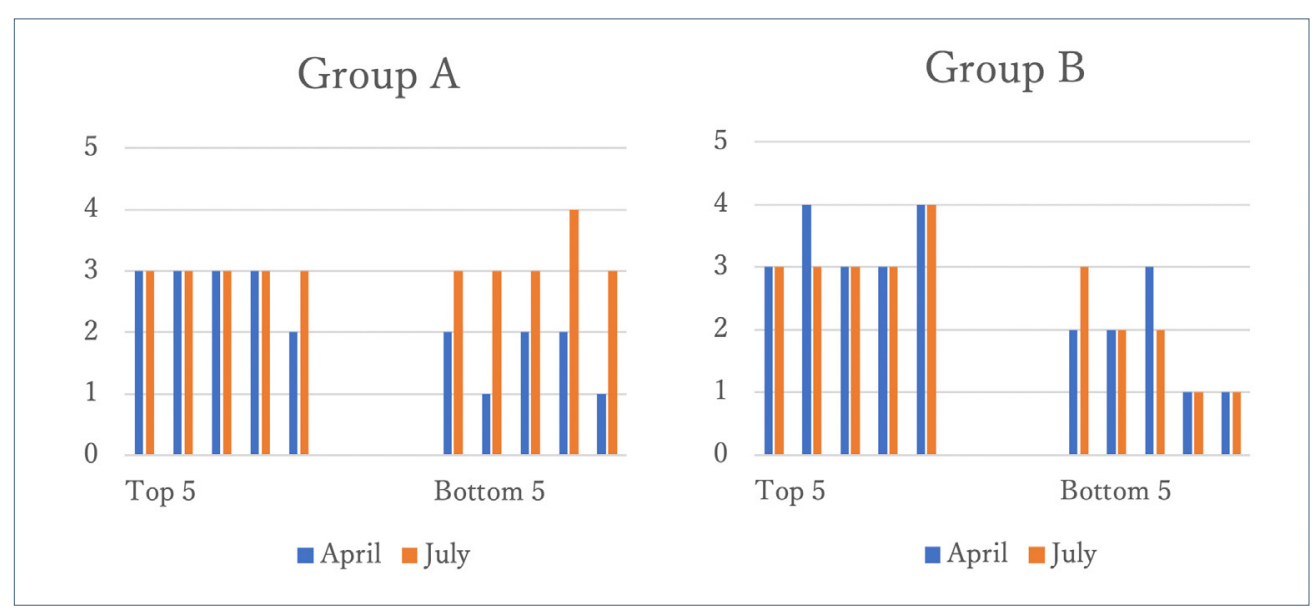

Figure 1. Top and bottom five performing participants' agreement with high self-efficacy statements in April and July.

The low performers in the intervention group, however, displayed an average increase of 1.6 points (on a five-point Likert scale) in agreement with these statements following 10 weeks of NPRM activities. This indication that the self-efficacy beliefs of low performers may be positively influenced by NPRMing adds a new dimension to Murphey and Arao's (2001) finding that exposure to NPRMs may be more successful in increasing self-efficacy beliefs in learners dissatisfied with previous language learning experiences. 


\section{Conclusion}

Learners' impressions of their own aptitude for language learning and peer support appeared to undergo positive change following NPRM activities. Additionally, learners expressing lower confidence or observed to be less proficient reported aspirational feelings resulting from NPRM exposure and expressed admiration for the NPRMs by means of Japanese respect language. These changes were less apparent or nonexistent in more confident participants. Many of the more confident students reported dissatisfaction with what they perceived as inadequate performance by the NPRMs, suggesting that teachers may aid this approach by more carefully ensuring that NPRMs are level-appropriate-i.e., matched more closely to the levels of the students.

This study did provide instructors with insight into the experiences and attitudes of a 1st-year class of Japanese majors studying in a Japanese university, but methodological limitations common to classroom EFL research were unavoidable. Due to logistical considerations, participants in this study were selected through convenience sampling. This limitation is often unavoidable in classroom research, but attempts to replicate or further explore these research findings should, if possible, include sampling procedures that allow for a higher degree of randomization, and therefore, greater generalizability. Researcher error may have contributed to oversights as well: several questionnaire items were written with the assumption that participants shared Japanese cultural upbringing but the unwitting inclusion of four Chinese exchange students' responses in the survey data sets may have affected these results, given that they are more culturally distant from the students selected as NPRMs. Naturally, future efforts to explore the relationship between learner beliefs and identity should ensure that data collection instruments and analytic tools are suited for heterogeneous student groups.

A number of observations and hypotheses emerging from this project appear wellsuited for future study. The predisposition for more advanced learners to respond less positively to NPRMing was first conjectured in 2001 by Murphey and Arao, and appears to be corroborated by this study's findings. However, a number of factors apart from learner confidence or ability (e.g., care in selection of NPRMs, differences in method, activity types, and the like) may be responsible for these observations and merit further exploration.

Both the findings and limitations of the current project highlight opportunities for research into the topic of NPRMing as one of many techniques suitable for use in the English language classroom. In the Japanese EFL context, where discussions of cultural identity persist and where learners continue to struggle with appropriate English interaction, NPRMing may be particularly meaningful. This author takes the position that it is essential to meet our students where they are, not where we may wish them to be, and that by presenting culturally distant role models as the "picture of success" in English speaking, teachers may be doing them a disservice. Young Japanese learners have relatively few role models who look like them and who share their experience, and may benefit greatly from increased awareness of other successful Japanese speakers of English.

\section{Bio Data}

Jason R. Walters is a lecturer and Assistant Director of the Core English Program at Nagoya University of Foreign Studies, and has lived in central Japan since 2009. His primary research interests include native speaker-ism in Asian EFL education, promoting learner autonomy through advising and self-access learning, and practical applications of positive psychology in the language classroom. <jwalters@nufs.ac.jp>

\section{References}

Bandura, A. (1997). Self-efficacy: The exercise of control. New York: Macmillan.

Bowyer, D. S. (2018). A mixed methods study of the effects of recursive practice and assessmentas-learning washback on learner performance and beliefs in oral communication EFL tutorials (Unpublished MA dissertation). Nagoya University of Foreign Studies, Nisshin, Japan.

Cook, V. (1999). Going beyond the native speaker in language teaching. TESOL Quarterly, 33(2), 185-209. https://doi.org/10.2307/3587717

Cottle, B. K. (2009). Representation of English users and uses in university EFL textbooks. The Language Teacher, 33(1), 3-8. Retrieved from https://jalt-publications.org/tlt/articles/587representation-english-users-and-uses-university-efl-textbooks

Dörnyei, Z., \& Murphey, T. (2003). Group dynamics in the language classroom. Cambridge: Cambridge University Press.

Haye-Matsui, A. (2018). "They Were Women and I Had a Cool Image About Them": Female Role Models and Female English Language Majors. The Language Teacher, 42(3), 3-7. Retrieved from https://jalt-publications.org/node/2/articles/24202-\%E2\%80\%9Cthey-were-women-and-i-hadcool-image-about-them\%E2\%80\%9D-female-role-models-and-femal

Horwitz, E. (1987). Surveying student beliefs about language learning. In A. L. Wenden \& J. Rubin (eds.), Learner strategies in language learning (pp. 119-129). Englewood Cliffs, NJ: Prentice-Hall.

Ito, Y. (2016). A comparison of elementary school English textbooks used in Japan, South Korea and China (Shanghai). JATLaC Journal, 11, 47-61.

Kichiji, S. (1997). Presenting alternative near peer role models for women in Japan (Unpublished senior thesis). Nanzan University, Nagoya, Japan. 
Kushida, Y. (1995). Near peer role models (Unpublished senior thesis). Nanzan University, Nagoya, Japan.

Law, G. (1995). Ideologies of English language education in Japan. JALT Journal, 17(2), 213-214.

Matsuda, A. (2002). Representation of users and uses of English in beginning Japanese EFL textbooks. JALT Journal, 24(2), 182-200. https://10.37546/JALTJJ24.2-5

Lipovsky, C., \& Mahboob, A. (2010). Appraisal of native and non-native English speaking teachers. The NNEST lens: Non native English speakers in TESOL, 154-179.

McKnight, P. E., \& Najab, J. (2010). Mann-Whitney U Test. The Corsini Encyclopedia of Psychology, 1-1. https://doi.org/10.1002/9780470479216.corpsy0524

McVeigh, B. J. (2002). Japanese higher education as myth. New York: ME Sharpe.

Murphey, T. (1998). Motivating with near peer role models. On JALT97: Trends \& Transitions, 201205. Retrieved from https://www.academia.edu/1902745/Motivating_with_near_peer_role_ models

Murphey, T. \& Arao, H. (2001). Reported belief changes through near peer role modeling. TESL-EJ, 5 (3), 1-15. Retrieved from https://www.tesl-ej.org/wordpress/issues /volume5/ej19/ej19a1/

Murphey, T., \& Murakami, K. (1998). Near peer role models and changing beliefs. Academia 65, $1-29$.

Phillipson, R. (1992). Linguistic imperialism. Oxford: Oxford University Press.

Reischauer, E. O., \& Jansen, J. (1988). The Japanese today: Continuity and change. Cambridge, MA: Harvard UP.

Stapleton, P. (2000). Culture's role in TEFL: an attitude survey in Japan. Language Culture and Curriculum, 13(3), 291-305.

Turnbull, B. (2017). Learner perspectives on national identity and EFL education in Japan: Report of a questionnaire study. The Journal of AsiaTEFL, 14(2), 211-227. https://doi.org/10.18823/ asiatefl.2017.14.2.1.211

Wang, L. Y., \& Lin, T. B. (2013). The representation of professionalism in native English-speaking teachers recruitment policies: A comparative study of Hong Kong, Japan,

Korea and Taiwan. English Teaching, 12(3), 5.

Yamashita, Y. (1998). Near peer role modeling in language learning histories (Unpublished senior thesis). Nanzan University, Nagoya, Japan.

Zirkel, S. (2002). Is there a place for me? Role models and academic identity among white students and students of color. Teachers College Record, 104(2), 357-376. https://doi.org/10.1111/14679620.00166

\section{Appendix A}

\section{Consent Form for Participants}

\section{Consent Form 同意書}

I give permission for my teacher to use my class information to help improve future PUT classes. This includes information about my classwork and homework.

私は、私の授業情報を、先生が行う学生の学習目標に関する実践研究プロジェクトのために使用されることに同意しま 寸。この授業情報には、私の授業課題や宿題が含まれます。

Name: Signed: Date: 氏名 署名 記入

I want my teacher: (choose one)

私は先生に：(該当する方を選んでください)

$$
\begin{aligned}
& \text { 口 to use my real name } \\
& \text { 本名を使って欲しい }
\end{aligned}
$$

give my permission for my teacher: (tick all that apply)

私は先生に以下のことを許可します：(該当するむの全てにっしてください)

$\square$ to audio record me $\mathrm{me}$ to video record me

音声の録音

動画の撮影

$\square$ to show other teachers and researchers my class work

他の先生や研究者に私の授業課題、宿題や試験を見せる

$\square$ to show other teachers and researchers my audio and video recordings 他の先生や研究者に私の録音・録画データを見せる 
Walters: Senpai: Learner Responses to a Near-Peer Role Modeling Intervention

\section{Appendix B}

MBALLI Survey Items, Japanese

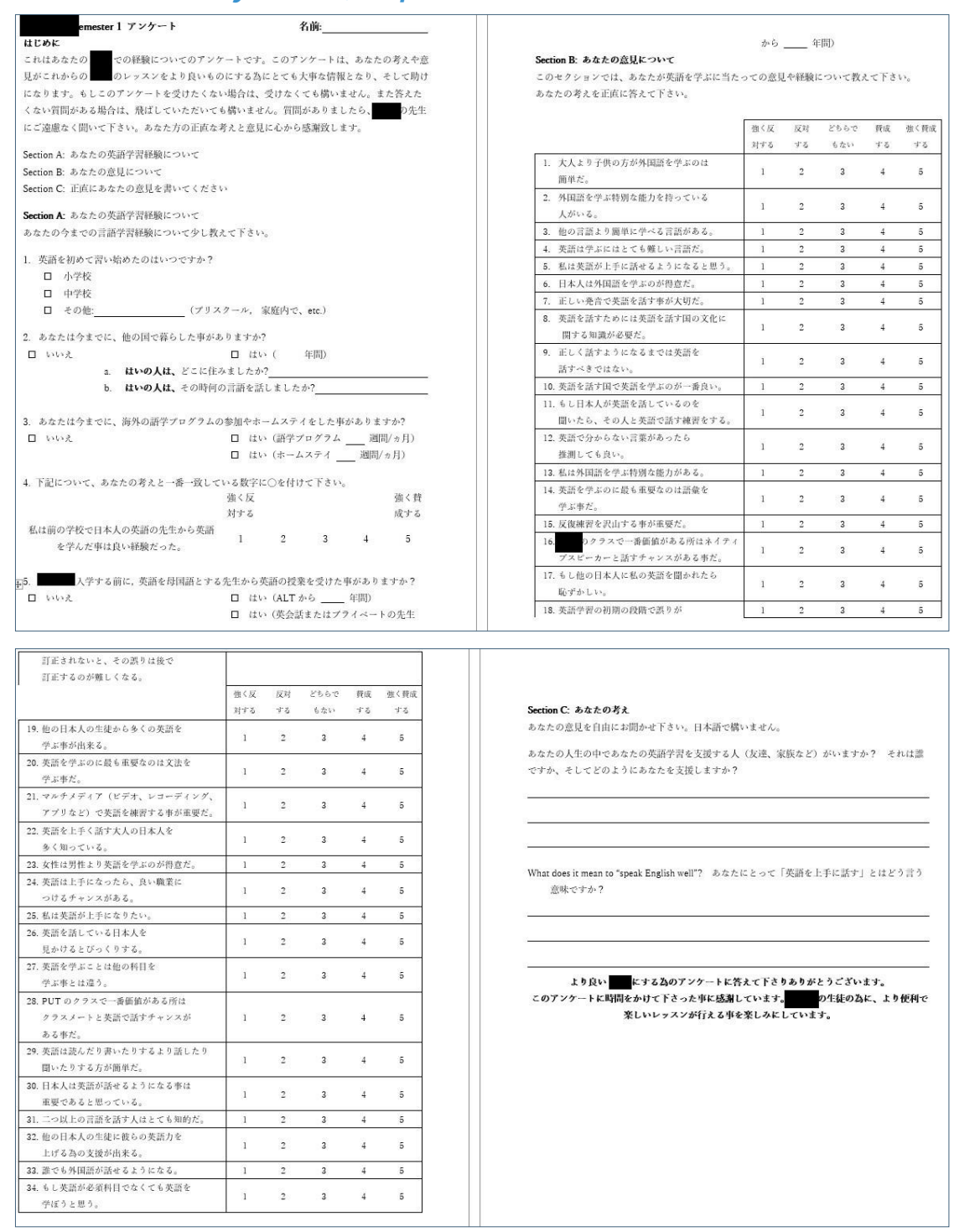

\section{Appendix C}

Preliminary Performance Rubric (Bowyer, 2018)

\begin{tabular}{|c|c|c|c|c|c|}
\hline \multicolumn{2}{|l|}{ Tutor: } & \multicolumn{3}{|l|}{ Group: } & Topic: \\
\hline & 1 & 2 & 3 & Score & Notes \\
\hline \begin{tabular}{|l} 
Content \\
\end{tabular} & \begin{tabular}{|l} 
Rarely provides detail \\
when phenking \\
Description
\end{tabular} & 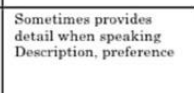 & 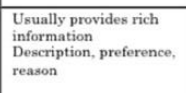 & & \\
\hline Participation & 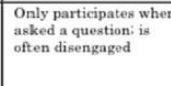 & 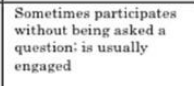 & 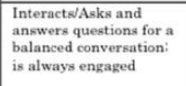 & & \\
\hline \begin{tabular}{|l|l} 
Understandability \\
\end{tabular} & 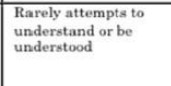 & 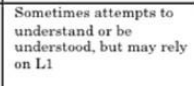 & 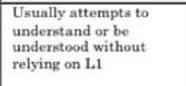 & & \\
\hline & & & Total Score: & & \\
\hline
\end{tabular}

